\title{
Contested World Order: The Delegitimation of International Governance
}

\author{
Liesbet Hooghe \\ W.R. Kenan Distinguished Professor, University of North Carolina Chapel Hill \\ Robert Schuman Fellow, EUI
}

Tobias Lenz

Assistant Professor at the University of Göttingen

Gary Marks

Burton Craige Distinguished Professor, University of North Carolina Chapel Hill Robert Schuman Fellow, EUI

\begin{abstract}
This article argues that the chief challenge to international governance is an emerging political cleavage, which pits nationalists against immigration, free trade, and international authority. While those on the radical left contest international governance for its limits, nationalists reject it in principle. A wide-ranging cultural and economic reaction has reshaped political conflict in Europe and the United States and is putting into question the legitimacy of the rule of law among states.
\end{abstract}

[Pre-publication version -- October 2018, forthcoming in Review of International Organizations, https://doi.org/10.1007/s11558-018-9334-3 ] 


\section{Introduction}

This paper builds on the Tallberg and Zürn approach to international legitimacy. Our argument is that a major policy shift from the early 1990s, which strengthened international organizations, has unleashed a delegitimating reaction in western societies. This targets some of the most prominent international organizations (IOs) directly, and has the more general effect of structuring domestic contestation around the very existence of rule-based international governance.

There is broad recognition that international governance is under stress. The predominant axis of debate hinges on whether the current international order will be undermined by rising nations as the hegemony of the United States (US) weakens. Constructivists engage this question by stressing the normative challenge that these states pose to western-dominated, rule-based, institutions (Acharya 2014). Neorealists predict a turbulent end to Pax Americana as the United States declines economically and militarily. ${ }^{1}$ Institutionalists point to the illiberal turn in rising nations and their attempts to project counter-norms (Diamond, Plattner, and Walker 2016). Those who disagree argue that rising nations will seek to reform, rather than eliminate, international governance. Writing in 2015, Ikenberry maintains that the liberal order will outlive US hegemony because it benefits rising as well as western states, and so what we are witnessing is "a crisis of the American governance of liberal order and not of the liberal order itself. The crisis of liberalism today will ultimately bring forth 'more liberalism'"' (Ikenberry 2010: 509; Ikenberry 2015; see also Kahler 2013).

Our contribution in this commentary is to examine the character and implications of domestic political contestation. This special issue is a valuable point of departure because it asks us to move beyond the interaction of states to engage the perceptions of actors regarding the legitimacy of 10 s. $^{2}$ The perspective it advances has the potential to build a vital bridge between the study of international organization and the field of comparative politics. However, we wish to broaden the approach taken in the special issue. Our premise is that international governance is now embedded in partisan conflict, and that its future depends on the mobilization of that conflict in the contest for control over national governments. To understand the future of international governance one must pay attention to the ideologies of political leaders and political parties. ${ }^{3}$

Recent research in comparative politics reveals that attitudes towards immigration, trade-exacerbated inequality, and loss of national sovereignty have gained greatly in salience

\footnotetext{
${ }^{1}$ Layne (2012) argues that China's views on international order are incompatible with those of the United States. Kissinger (2014) warns that unipolarism will be replaced by competition between four regional blocks with incompatible worldviews: European post-Westphalian, Islamic, Chinese, and American.

${ }^{2}$ See especially Anderson, Bernauer, and Kachi (2019); and Schmidtke (2019).

${ }^{3}$ We understand ideology in a broad sense as a set of normative beliefs and values about the proper order of society and how it can be brought about (Jost, Federico, and Napier 2009: 309).
} 
over the past decade. ${ }^{4}$ In Europe, a new cleavage has emerged which has as its core a political reaction against European integration and immigration (Hooghe and Marks 2018; Kriesi et al. 2006; Whitefield and Rohrschneider 2016). The key issues relate to the defense of national community against transnational shocks. In the United States, the reaction against immigration, the North American Free Trade Agreement (NAFTA), and globalization has intensified partisanship, corroded democratic norms, and led to the election of a president deeply critical of IOs. Public opinion research reveals that immigration, trade and the perceived decline of US dominance are significant drivers of support for Donald J. Trump (Autor et al. 2017; BallardRosa et al. 2018; Cerrato, Ferrara, and Ruggieri 2018; Jensen et al. 2017; Mutz 2018).

This suggests that international governance is challenged from within its democratic core as well as beyond it. ${ }^{5}$ To understand the tensions arising from internationalism, we need to broaden our point of view beyond relations among countries to conflict within them. Ironically, the most acute threat to international governance stems not from its inability to serve nonWestern countries, but from its perceived failure to help large numbers of voters at home.

The point of departure for the contemporary crisis of legitimacy of international governance is a series of major reforms in the early 1990s that reduced barriers to transnational economic exchange. The 1990s were at the cusp of a rapid increase in international trade, international migration, and economic inequality that have their ideological roots in the Thatcher-Reagan years. The dissolution of the Soviet empire in 1989 released more than one hundred million people to trade and circulate within the European Union (EU). The World Trade Organization (1994) was negotiated in the early 1990s, as were regional trade organizations, now totaling thirty-five in number (Hooghe et al. 2017). NAFTA (1992) was intended to eliminate trade and investment barriers in North America. The Maastricht Treaty (1993), negotiated in the early 1990s, extended EU authority over wide ranges of public life, made it much easier for people to work in another EU country, created a common currency, and turned nationals into European Union citizens. The 1990s saw a marked increase in delegation to international organizations beyond the European Union. Around four in five regional IOs have seen an increase in delegation to non-state bodies since their founding.

The net effect of this institutional creativity has been to diminish the cost of international trade and migration while diffusing authority from central states to bodies within and among them. This involved the creation and empowerment of IOs-formally constituted rule-based institutions with an ongoing capacity for problem solving. IOs rest on agreement among member states, but to some extent all pool authority among states in majoritarian

\footnotetext{
${ }^{4}$ On Europe, see Bechtel, Hainmueller, and Margalit (2014); De Vries (2018); Häusermann and Kriesi (2015); Rydgren (2013); Teney, Lacewell, and De Wilde (2014); Van Elsas, Hakhverdian, and van der Brug (2016). On Brexit, see Hobolt (2017); Hobolt, Leeper, and Tilley (2018).

${ }^{5}$ Our argument highlights nationalist mobilization in the liberal heartland as the chief source of instability, but this is compounded by opposition from rising powers and authoritarian rulers. Rising powers may challenge 10 governance because it reflects the interests and norms of its Western founders. Authoritarian rulers may reject 10 authority because it queries their hold on power. Interestingly, challenges from rising powers or from authoritarian rulers are also often couched in a nationalist rhetoric.
} 
decision making and delegate authority to independent non-state actors, including secretariats and courts. The institutionalization of international governance sought to impose the rule of law on relations that were previously determined by power. ${ }^{6}$ This provided a basis for cooperation in lowering the barriers to transnational exchange. Yet, the unintended consequence was to bring transnational exchange and international governance into domestic politics.

In the next section, we outline key insights and shortcomings of the Tallberg and Zürn model of legitimacy and legitimation. The following section builds on this to compare the opposition of radical leftists and radical nationalists to IOs. The thrust of our argument is that even if some IOs are more directly targeted than others, the liberal world order that matured in the past two decades is now fundamentally contested.

\section{Ideological Conflict in the Tallberg-Zürn Framework}

Tallberg and Zürn adopt a sociological perspective in the tradition of Max Weber which conceives legitimacy as the "beliefs of audiences that an IO's authority is appropriately exercised" (Tallberg and Zürn 2019: 4). Legitimacy is understood as a motivational force for rule-following and social order that rests on moral obligation that is distinct from both selfinterest and coercion. In the words of Tallberg and Zürn, legitimacy requires a "reservoir of confidence in an institution that is not dependent on short-term satisfaction with its distributional outcomes" (Tallberg and Zürn 2019: 11). By stressing perceptions of international authority, this sociological perspective puts the spotlight on why and when actors believe that they are morally obliged to obey (Tallberg and Zürn 2019: 4; see also Zürn, Binder, and EckerEhrhardt 2012; Zürn 2018; Lenz and Viola 2017). This has the virtue of problematizing both instrumental and expressive sources of IO support and opposition. ${ }^{7}$

Tallberg and Zürn argue that the legitimacy of an IO depends on how it is designed, how it makes decisions, and what those decisions are. Hence, the framework gives analytical primacy to the 10 itself: the scope and depth of its authority; its inclusiveness, transparency, and representativeness; how efficient, effective, and fair it is in carrying out its tasks. These evaluations depend on an actor's cognitive and affective priors. The public, alongside NGOs, the media, and elites, rely on shortcuts in assessing the legitimacy of an IO's authority, procedures, and performance.

This analytical framework is carried forward in the contributions to this special issue. Anderson, Bernauer, and Kachi (2019) show that citizens' legitimacy perceptions of global governance institutions are shaped by procedural and performance quality. Schmidtke (2019)

\footnotetext{
${ }^{6}$ The rule of law was long alien to international relations. The first time that the UN Security Council expressly made reference to the principle was in 1996 (Bingham 2010: 117; see also Alvarez 2005). Beginning in the 1990s, International Relations scholars developed new concepts to come to grips with this development: legalization (Goldstein et al. 2000), institutional design (Koremenos, Lipson, and Snidal 2001), and judicialization (Romano, Alter, and Shany 2014).

${ }^{7}$ See the 200510 special issue on international institutions and socialization which problematized how agents' priors constrain international socialization (Checkel 2005).
} 
focuses on public interest groups, finding that elite cues are most intense for IOs exerting extensive authority. Nielson, Hyde, and Kelley (2019) evaluate the legitimacy of election observers in the eyes of non-governmental organizations (NGOs), and find that the important factor is experience.

Can one generalize about how actors arrive at affective and cognitive shortcuts? An extensive literature highlights the way in which ideology structures opinions over political objects. Tallberg and Zürn provide an opening in this direction when they write that "IO legitimacy is ... formed in a context of societal norms about the appropriate exercise of authority ... [L] egitimation as a process of justification and contestation intended to shape such beliefs" (Tallberg and Zürn 2019: 12, 4, our emphasis). In the language of the special issue, can one generalize about the societal norms that frame actors' beliefs about the appropriate exercise of authority?

\section{Domestic Contestation about International Governance}

Counter-movements of leftists and nationalists have been at the forefront in challenging the legitimacy of $10 .^{8}$ Opposition began on the left, though in most recent years it been strongest among nationalists who frame their opposition to international governance as defense of the nation against transnational influences, above all immigrants.

The leftist critique of international governance contains multiple strands, including a trade unionist component; a radical leftist strand with ties to participatory democracy, feminism, and the rights of indigenous peoples; a green or environmentalist component; and, around its edges, diverse groups with anarchist leanings. ${ }^{9}$ From the early 1970 s, a coalition formed among these groups to oppose trade deals on the ground that economic integration in a world of segmented sovereignty would make governments subservient to the power of capital. The fear was that competition among governments for footloose capital would weaken unions, outflank environmental legislation, and undermine democracy. ${ }^{10}$

This has motivated leftist opposition to several regional IOs, including NAFTA. Fears of job loss, rising inequality, and downward pressure on environmental and health standards were intensified because NAFTA insulated trade from social, welfare, and environmental concerns

\footnotetext{
${ }^{8}$ This argument builds on a growing literature that investigates the politicization of IOs. See e.g. Conceição-Heldt (2013); Ecker-Ehrhardt (2014); Hooghe and Marks 2009; Hooghe, Lenz, and Marks (2019); Hurrelmann and Schneider (2015); Kay (2015); Mansfield and Mutz (2012); Morgenstern et al. (2007); Rathbun (2012); Rixen and Zangl (2013); Zürn (2004); Zürn, Binder, and Ecker-Ehrhardt (2012).

${ }^{9}$ For exhaustive discussions of the global justice movement which comprises these strands, see Baumgarten (2017); Della Porta (2007); Smith et al. (2016). For discussions of the left's mobilization to build a social Europe, see Hooghe and Marks (1999); Rhodes and van Apeldoorn (1997); Ross (1995).

${ }^{10}$ Anderson, Bernauer, and Kachi (2019) find that the second-most important reason why survey respondents in Germany and the United States perceive a hypothetical Global Climate Conference to be undemocratic is because they fear that business interests dominate negotiations.
} 
(Schimmelfennig et al. 2018). ${ }^{11}$ In the European Union, radical left parties in Greece, Spain, France, and Germany have been sharply critical of EU-coordinated austerity in the wake of the Euro-crisis, and have demanded counter-measures, including European bonds, tighter EU regulation of banks, and a larger EU budget (Tsoukalis 2014; Varoufakis 2017). In Mercosur, trade unions and civil society organizations have been skeptical about the IO's focus on trade liberalization (Grugel 2007; Olivet and Brennan 2010). A diverse leftist coalition, including the Inter-American Regional Organization for Workers and the Hemispheric Social Alliance alongside leftist governments, blocked a US-supported Free Trade Area of the Americas (FTAA) because it did not encompass social policy or social rights (Briceño Ruiz 2007). Civil society groups made similar objections to the Central American Free Trade Agreement (Spalding 2007).

Leftist opposition has also targeted global IOs. In Fall 1999, tens of thousands of activists chanting "no globalization without representation!" broke up a ministerial WTO meeting in Seattle (Munck 2007: 60). Jay Mazur, president of the American Union of Needletrades, Industrial and Textile Employees (UNITE), saw this as a turning point: "The era of trade negotiations conducted by sheltered elites balancing commercial interests behind closed doors is over" (Mazur 2000: 79). A transnational "Teamster-Turtle" Alliance of organized labor, environmentalists, community groups, and anti-capitalist youth demanded that liberalization be coupled with labor rights, fair wages, and environmental standards. In Kaldor's (2000) memorable phrase this is a call to "civilize globalization."

These examples reveal that the left coalition does not reject international authority in principle. The most vocal leftist opponents of trade liberalization are ardent supporters of a more social, liberal, green, and democratic international organization (Burgoon 2009; Caporaso and Tarrow 2009). The slogan of the Global Justice Movement is "Another World is Possible," an explicit refutation of Margaret Thatcher's "There is no Alternative" (to neoliberal free trade) (Baumgarten 2017: 647). This is a demand for more, rather than less, international authority (Bexell, Tallberg, and Uhlin 2010; Jönsson and Tallberg 2010; Keck and Sikkink 1998; O'Brien et al. 2000; Simmons 2009; Steger and Wilson 2012; Tarrow 2005). The movement for a "social Europe" was expressed in the demand for empowering the European Parliament, for greater redistribution, and for EU-wide social regulation. In Latin America, opponents of the US-led FTAA and the "Washington Consensus" sought to deepen Mercosur and the Andean Community as a countervailing force. International authority itself was not contested-its scope, depth, and form were.

This cannot be said of radical nationalists. President Trump, Marine Le Pen and the French National Rally, Matteo Salvini and the Northern League in Italy, and Geert Wilders and the Party for Freedom and Progress in the Netherlands reject international organization in principle as well as in practice. In a speech launching her campaign for the 2017 presidential race, Le Pen made globalization the enemy, linking it to Islamist fundamentalism as a force that will "subjugate our country" and "make our nation disappear." Le Pen promised to pull France out of the Eurozone, the North Atlantic Treaty Organization (NATO), and, more generally, regain

\footnotetext{
${ }^{11}$ At the eleventh hour, the Clinton administration secured two side accords custom-tailored to allay particular US environmental and labor concerns (Morgenstern et al. 2007). For an astute analysis of the politics surrounding the genesis and development of NAFTA, see Bow and Santa Cruz (2015).
} 
"our territorial sovereignty." President Trump is similarly committed to regaining national sovereignty, and has openly questioned the rule of international law in a speech to the Central Intelligence Agency in which he suggested that the spoils of war belong to the victor. ${ }^{12}$ In its first two years of office, the Trump administration has pulled the United States out of the Paris Climate Change Agreement, withdrawn from the United Nations Education, Scientific and Cultural Organization, reigned in legal and illegal immigration from non-Western countries, and renegotiated NAFTA.

The radical nationalist reaction to international governance is sharply different from the neoliberal critique that gained traction in the 1980s and 1990s. While neoliberals opposed broadly authoritative international governance, they supported IOs, including NAFTA and the EU, to achieve market deregulation and limited government. ${ }^{13}$ Along these lines, British Prime Minister Margaret Thatcher championed the European single market project and opposed overarching regulation. In her speech at the College of Europe in 1988, she declared "the need for [European] Community policies which encourage enterprise" and for "removing barriers to trade ... in the multilateral negotiations in the GATT," but she saw no further role for EU institutions: "we have not successfully rolled back the frontiers of the state in Britain, only to see them re-imposed at a European level, with a European superstate."

Recent comparative research suggests that today the delegitimation of IOs is more than a clash of policies. It appears to be part of a new social cleavage that is transforming the structure of conflict, pitting cultural and economic losers of transnationalism against the winners. Many feel left behind by an economic and cultural transformation that has diminished the protective capacity of the nation state (Hochschild 2016; Inglehart and Norris 2016). National borders have been perforated by immigration, international trade, and in Europe, by the melding of states in a multilevel polity.

This transnational cleavage is independent of conventional left-right conflict about the role of government and welfare. At the nationalist pole are those who want to defend "national political, social and economic ways of life against external actors who penetrate the state by migrating, exchanging goods, or exerting rule." At the cosmopolitan pole are those who conceive their national identity as consistent with international governance and who welcome, rather than oppose, the dense interpenetration of societies (Hooghe and Marks 2018: 2).

12 "When I was young, we were always winning things in this country. We'd win with trade. We'd win with wars. At a certain age, I remember hearing from one of my instructors, "The United States has never lost a war." And then, after that, it's like we haven't won anything. We don't win anymore. The old expression, "to the victor belong the spoils" -- you remember. I always used to say, keep the oil. I wasn't a fan of Iraq. I didn't want to go into Iraq. But I will tell you, when we were in, we got out wrong. And I always said, in addition to that, keep the oil." Full text: Trump, Pence remarks at CIA Headquarters on January 23, 2017: http://www.cbsnews.com/news/trump-cia-speech-transcript/

${ }^{13}$ Neoliberal ideas on international authority were influential in the structural adjustment programs of the International Monetary Fund and the World Bank in the 1980s and 1990s, the creation of the World Trade Organization in 1995, and the phenomenal rise in preferential trade agreements in the 1990s (Haggard and Kaufman 1992). 
The roots of this cleavage reach into social structure. Nationalists and cosmopolitans are sharply distinguished by gender, occupation, rural-urban location, and above all, by education (Golder 2016; Marks et al. 2018; Van Elsas, Hakhverdian, van der Brug 2016). Nationalist parties are composed disproportionately of white working men who perceive loss of status (Hetherington and Weiler 2018; Marks et al. 2018; Mutz and Kim 2017). Many white Americans are anxious about their oncoming minority status and fear the erosion of US hegemony (Mutz 2018: 2-3). Individuals with lower subjective social status are significantly more likely to believe that immigrants take jobs away from the native born and that their country should limit imports (Gidron and Hall 2017: 70-72). The Brexit vote has a similar structure. Leavers tend to have strongly unfavorable opinions on immigration, multiculturalism, and globalization, and to feel that they suffer both culturally and economically from the exercise of international governance.

\section{The Constraints of Domestic Contestation on IO Governance}

The contrasting stances of nationalist and radical left political parties can be gauged with original data. Figure 1 depicts the ideological positions of 191 political parties in fourteen EU member states between 1999 and 2017. The X-axis represents the median level of support among nationalist, radical left, and green parties for internal market liberalization, European integration, and a range of EU market-correcting policies. Both the median nationalist party and radical left party oppose Europe's internal market, but they have sharply different views on EU institutions and market-correcting policies. Nationalist parties oppose Europe across the board, whereas the radical left would like to see more, not less, supranationalism. Nationalist and radical left political parties have consistently divergent attitudes on the European parliament's powers, employment policy, environmental policy, and asylum policy. In this field, to reverse the classic expression, the extremes do not touch.

The slogan of the European-wide association of radical left parties in the 2014 European parliamentary elections was "Escaping Austerity, Rebuilding Europe." Its manifesto rejected nationalism and ethnocentrism. Nationalist parties, by contrast, see the EU as a threat to national community as well as a source of economic insecurity. In the March 2018 national elections, the Italian Northern League competed on the slogan "Slaves of Europe? No, thanks!" Both Bernie Sanders and Donald Trump rejected NAFTA during the 2016 presidential campaign, but in contrasting ways. Donald Trump claimed he would raise tariffs unilaterally and tear up trade agreements, while Bernie Sanders said he would honor existing deals as he renegotiated them (Carter 2016). 


\section{Figure 1: Contesting Europe: Breakdown by policy and party group}

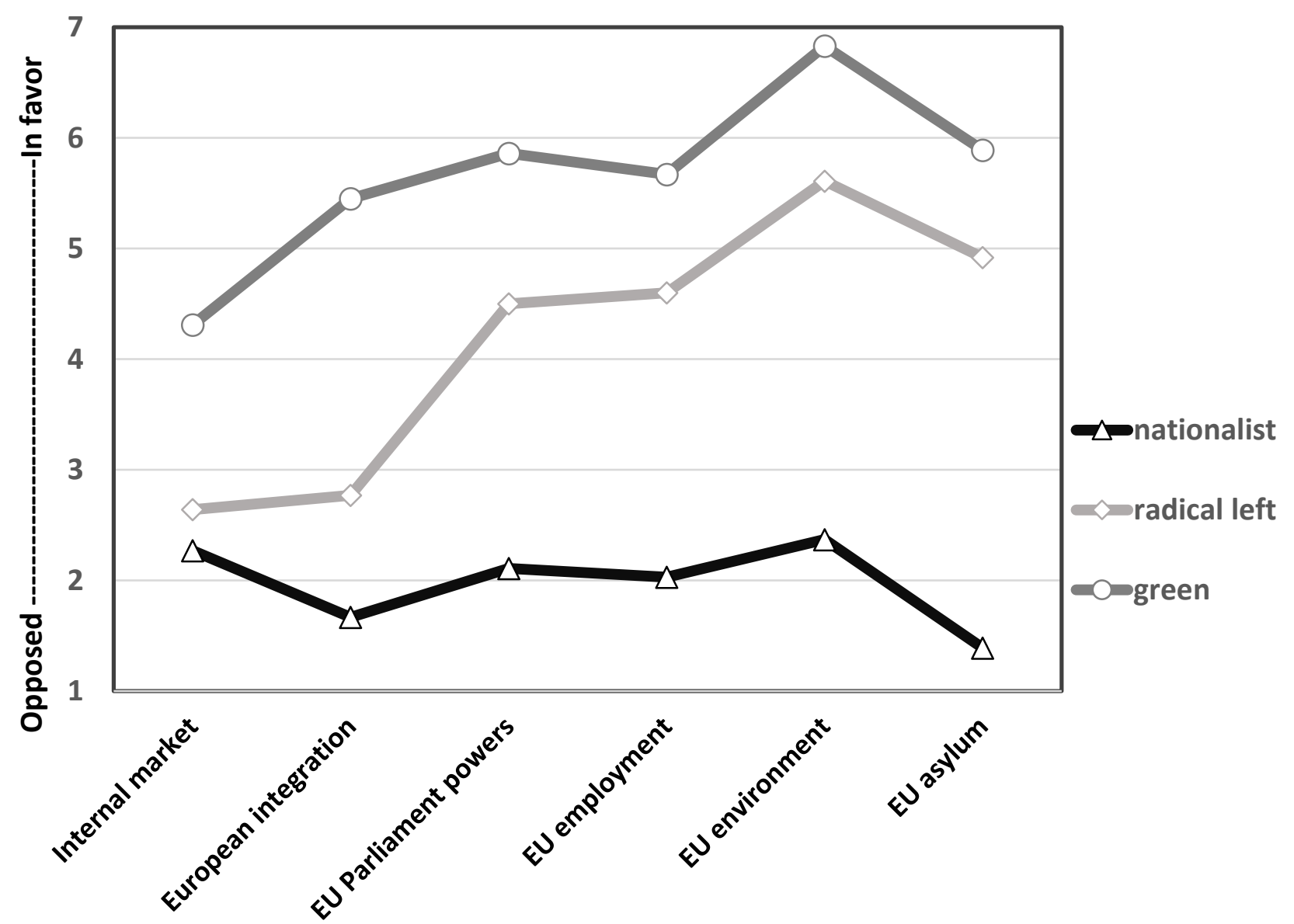

Source: Chapel Hill Expert Survey Data on the positioning of national political parties on EU policies (Polk et al. 2017). Each item ranges from 1 (strongly opposed) to 7 (strongly in favor). Median expert assessments across six time points $(1999,2002,2006,2010,2014,2017)$ for fourteen EU member states (Czech Republic, Estonia, France, Germany, Greece, Hungary, Italy, Netherlands, Poland, Portugal, Slovakia, Spain, Sweden, UK). Nationalist parties $(N=61)$, radical left parties $(N=79)$, green parties $(N=51)$ that obtained at least 2 percent of the vote in the most recent national election prior to the time point of evaluation. Data available from: https://www.chesdata.eu/

Interestingly, green parties, which are sometimes placed under the radical left umbrella, favor internationalization across the board, though they are less enthusiastic on the internal market than on European integration more generally. In recent years, green parties have become outspoken advocates of transnationalism. Support for international institutions, particularly IOs with a capacity to regulate economic activity beyond the national state, is integral to their political program.

Whereas nationalists reject international governance because it undermines state sovereignty, those on the left evaluate an 10 in light of its potential for social regulation. The contrast between the EU and NAFTA is a case in point. The European Union is a general purpose 10 which offers the prospect of governance on a broad front. By contrast, NAFTA is a task- 
specific 10 with a policy portfolio that is limited to free trade. ${ }^{14}$ The appeal of a general purpose IO such as the European Union is that, unlike NAFTA, it holds the promise of regulating powerful economic interests and of redistributing from rich to poor regions. The fact that the EU has a directly elected parliament underpins this potential (Rocabert et al. 2019).

Several IOs have sought to respond to the criticisms of the radical left by enhancing participation and transparency and, to some extent, by engaging regulatory issues beyond trade and investment. IOs have opened channels to social groups, created consultative bodies of parliamentarians, and strengthened access for civil society stakeholders (Tallberg et al. 2013; Rocabert et al. 2019). This has gone hand in hand with democratic rhetoric and transparency (Dingwerth et al. 2015; Ecker-Ehrhardt 2017). Several IOs have made an effort to incorporate social, cultural, and other non-economic concerns in trade and investment. In the early 2000s, a US-French proposal, backed by the European Parliament, sought to include labor standards in the WTO. The proposal was defeated, but "the Marrakesh meeting gave the trade union drive for enforceable 'international worker rights standards' far greater credibility" (French 2002: 286) and spawned a round of pre-emptive legitimation including a World Bank publication, Workers in an Integrating World, and the UN's Global Compact (Higgott 2000). ${ }^{15}$ Latin American regional organizations have adopted a social, educational, and cultural agenda (Ribeiro Hoffmann 2015: 64).

It is vastly more difficult for IOs to respond to criticism from radical nationalists. Nationalists aim their sharpest barbs at general purpose IOs because they are the nearest thing in the international domain to government, the exercise of authority across a wide, incompletely contracted, policy field on behalf of a transnational community. General purpose IOs are anathema for those who conceive national identity in zero-sum terms. To the extent that task-specific IOs exert supranational authority, they too weaken control over the nation's destiny. Le Pen wants France to leave the military structure of NATO as well as the European Union, and for the same reason: "so that France would not be dragged in wars that are not its own."

\section{Conclusion}

We are witnessing unprecedented opposition to post-war international governance in its heartland: Europe and the United States. In this commentary, we suggest that IO legitimacy is embedded in ideological contestation. When viewed from this angle, some striking developments come into view. IOs have served as the basis for the international order

\footnotetext{
${ }^{14}$ It is doubtful whether NAFTA's successor, the recently concluded US-Mexico-Canada Agreement (USMCA), can be categorized as an international organization, "a formal organization for collective decision making constituted by three or more states ... structured by rules for a continuous purpose" (Hooghe et al. 2017: 14-15). A sunset clause triggers automatic expiration after sixteen years unless formally renewed by the three parties.

${ }^{15}$ Global Compact, written under the guidance of John Gerald Ruggie, was announced by UN Secretary General Kofi Annan in his Address to the World Economic Forum in Davos, Switzerland, Jan 31, 1999 (Press Release SG/SM/6881).
} 
following World War Two. Bretton Woods institutions-the International Monetary Fund, the World Bank and the General Agreement on Tariffs and Trade-were responsible for maintaining a stable world economy based on the principle of non-discrimination in an effort to avoid mutually exclusive economic blocs and beggar-thy-neighbor policies. The system also legitimated economic intervention at the national level-a grand political bargain that Ruggie (1982) termed "embedded liberalism."

After the Cold War this bargain was recast in a wave of institutional reform that facilitated international economic exchange and migration by empowering IOs that extended the rule of law among states. Contrary to the era of embedded liberalism, this new international order gave states much less discretion for shielding their populations from the insecurities of transnationalism. International governance succeeded in diminishing the cost of exchange across national borders, and its aggregate effect was to increase human welfare. However, it has generated a profound cultural and economic reaction in the states that launched the reforms. The debate over international governance features prominently in partypolitical programs; it influences national elections; and it is reshaping the structure of political conflict in Europe and the United States. Beyond the characteristics of individual IOs, there appear to be some clearly articulated ideological patterns in the delegitimation of IOs. 


\section{References}

Acharya, A. (2014). The End of the American World Order. London: Polity Press.

Alvarez, J. E. (2005). International Organizations as Law-Makers. Oxford: Oxford University Press.

Anderson, B., Bernauer, T., \& Kachi, A. (2019). Does International Pooling of Authority Affect the Perceived Legitimacy of Global Governance? Review of International Organization [this issue].

Autor, D., Dorn, D., Hanson, G., \& Majlesi, K. (2017). “Importing Political Polarization? The Electoral Consequences of Rising Trade Exposure." MIT Working Paper.

Ballard-Rosa, C., Jensen, A., \& Scheve, K. (2018). "Economic Decline, Social Identity, and Authoritarian Values in the United States." Paper presented at the American Political Science Association, Boston.

Baumgarten, B. (2017). The Global Justice Movement: Resistance to Dominant Economic Models of Globalization. In S. Berger \& H. Nehring (Eds.), The History of Social Movements in Global Perspective (pp. 647-676). London: Palgrave Macmillan.

Bechtel, M., Hainmueller, J., \& Margalit, Y. (2014). Preferences for International Redistribution: The Divide over the Eurozone Bailout. American Journal of Political Science, 58(4), 835-856.

Bexell, M., Tallberg, J., \& Uhlin, A. (2010). Democracy in Global Governance: The Promises and Pitfalls of Transnational Actors. Global Governance, 16(1), 81-101.

Bingham, T. (2010). The Rule of Law. London: Allen Lane.

Bow, B., \& Santa Cruz, A. (2015). Polls, Parties, Politicization, and the Evolution of North American Regional Governance. In B. Bow \& G. Anderson (Eds.), Regional Governance in Post-NAFTA North America (pp. 178-206). New York: Routledge.

Briceño Ruiz, J. (2007). Strategic Regionalism and Regional Social Policy in the FTAA Process. Global Social Policy, 7(3), 294-315.

Burgoon, B. (2009). Globalization and Political-Economic Backlash: Polanyi's Revenge? Review of International Political Economy, 16(2), 145-177.

Caporaso, J., \& Tarrow, S. (2009). Polanyi in Brussels: Supranational Institutions and the Transnational Embedding of Markets. International Organization, 63(4), 593-620.

Carter, Z. (2016). Bernie Sanders Says He Would Renegotiate NAFTA, Not Violate it. Huffington Post, 04/08/2016.

Cerrato, A., Ferrara, F. M., \& Ruggieri, F. (2018). Why Does Import Competition Favor Republicans? Localized Trade Shocks, Voting Behavior, and Scapegoating in the U.S. Available at SSRN: https://ssrn.com/abstract=3147169, from 28 March 2018.

Checkel, J. T. (2005). International Institutions and Socialization in Europe: Introduction and Framework. International Organization, 59(4), 801-826. 
Conceição-Heldt, E. da. (2013). Two-level Games and Trade Cooperation: What Do We Now Know? International Politics, 50(4), 579-599.

Della Porta, D. (Ed.). 2007. The Global Justice Movement: Crossnational and Transnational Perspectives. Oxon: Routledge.

De Vries, C. E. (2018). The Cosmopolitan-Parochial Divide: Changing Patterns of Party and Electoral Competition in the Netherlands and Beyond. Journal of European Public Policy, 25(11), 1541-1565.

Diamond, L., Plattner, M. F., \& Walker, C. (Eds.). (2016). Authoritarianism Goes Global: The Challenge to Democracy. Baltimore: Johns Hopkins University.

Dingwerth, K., Lehmann, I., Reichel, E., Weise, T., \& Witt, A. (2015). Many Pipers, Many Tunes? Die Legitimitätskommunikation internationaler Organisationen in komplexen Umwelten. Politische Vierteljahresschrift, 49, 186-212.

Ecker-Ehrhardt, M. (2014). Why Parties Politicise International Institutions: On Globalisation Backlash and Authority Contestation. Review of International Political Economy, 21(6), 1275-1312.

Ecker-Ehrhardt, M. (2017). Self-Legitimation in the Face of Politicization: Why International Organizations Centralized Public Communication. Review of International Organizations, https://doi.org/10.1007/s11558-017-9287-y

French, J. D. (2002). From the Suites to the Streets: The Unexpected Re-emergence of the 'Labor Question,' 1994-1999. Labor History, 43(3), 285-304.

Gidron, N., \& Hall, P. (2017). The Politics of Social Status: Economic and Cultural Roots of the Populist Right. British Journal of Sociology, 68(S1), 57-84.

Golder, Matt. (2016). Far Right Parties in Europe. Annual Review of Political Science, 19, 477-497.

Goldstein, J., Kahler, M., Keohane, R. O., \& Slaughter, A.-M. (2000). Legalization and World Politics. International Organization, 54(3), 385-399.

Grugel, J. (2007). Regionalist Governance and Transnational Collective Action in Latin America. Economy and Society, 35(2), 209-231.

Haggard, S., \& Kaufman, R. (Eds.). (1992). The Politics of Economic Adjustment. Princeton: Princeton University Press.

Häusermann, S., \& Kriesi, H. (2015). What Do Voters Want? Dimensions and Configurations in Individual-Level Preferences and Party Choice. In P. Beramendi, S. Häusermann, H. Kitschelt, \& H. Kriesi (Eds.), The Politics of Advanced Capitalism (pp. 202-230). Cambridge: Cambridge University Press.

Hetherington, M., \& Weiler, J. (2018). Prius or Pickup? How the Answers to Four Simple Questions Explain America's Great Divide. New York: Harcourt Publishing.

Higgott, R. (2000). Contested Globalization: The Changing Context and Normative Challenges. Review of International Studies, 26(5), 131-153. 
Hobolt, S. B., Leeper, T., \& Tilley, J. (2018). “Divided by the Vote: Affective Polarization in the Wake of Brexit." Paper presented at the American Political Science Association, Boston.

Hobolt, S. B. (2017). The Brexit Vote: A Divided Nation, A Divided Continent. Journal of European Public Policy, 23(9), 1259-1277.

Hochschild, A. R. (2016). Strangers in Their Own Land. New York: New Press.

Hooghe, L., \& Marks, G. (1999). Making of A Polity: The Struggle over European Integration. In H. Kitschelt, G. Marks, P. Lange, \& J. Stephens (Eds.), Continuity and Change in Contemporary Capitalism (pp. 70-79). Cambridge: Cambridge University Press.

Hooghe, L., \& Marks, G. (2009). A Postfunctionalist Theory of European Integration: From Permissive Consensus to Constraining Dissensus. British Journal of Political Science, 39(1), 1-23.

Hooghe, L., Marks, G., Lenz, T., Bezuijen, J., Ceka, B., \& Derderyan, S. (2017). Measuring International Authority: A Postfunctionalist Theory of Governance, Vol. III. Oxford: Oxford University Press.

Hooghe, L., \& Marks, G. (2018). Cleavage Theory Meets Europe's Crisis: Lipset, Rokkan, and the Transnational Cleavage. Journal of European Public Policy, 25(1), 109-135.

Hooghe, L., Lenz, T. \& Marks, G. (2019). A Theory of International Organization. Oxford: Oxford University Press.

Hurrelmann, A., \& Schneider, S. (Eds.). (2015). The Legitimacy of Regional Integration in Europe and the Americas. Houndmills, Basingstoke: Palgrave MacMillan.

Ikenberry, G. J. (2010). The Liberal Order and Its Discontents. Millennium: Journal of International Studies, 38(3), 509-521.

Ikenberry, G. J. (2015). The Future of the Liberal World Order. Japanese Journal of Political Science, 16(3), 450-455.

Inglehart, R. F., \& Norris, P. (2016). "Trump, Brexit, and the Rise of Populism: Economic Have-Nots and Cultural Backlash." Paper presented at the American Political Science Association, Philadelphia.

Jensen, J. B., Quinn, D. P., \& Weymouth, S. (2017). Winners and Losers in International Trade: The Effects on US Presidential Voting. International Organization, 71(3), 423457.

Jönsson, C., \& Tallberg, J. (Eds.). (2010). Transnational Actors in Global Governance: Patterns, Explanations, and Implications. London: Palgrave MacMillan.

Jost, J., Federico, C. M., \& Napier, J. L. (2009). Political Ideology: Its Structure, Functions, and Elective Affinities. Annual Review of Psychology, 60, 307-337.

Kahler, M. (2013). Rising Powers and Global Governance: Negotiating Change in a Resilent Status Quo. International Affairs, 89(3), 711-729.

Kaldor, M. (2000). 'Civilising' Globalisation?' The Implications of the 'Battle in Seattle.' Millennium: Journal of International Studies, 29(1), 105-114. 
Kay, T. (2015). New Challenges, New Alliances: Union Politicization in a Post-NAFTA Era. Labor History, 56(3), 246-269.

Keck, M., \& Sikkink, K. (1998). Activists Beyond Borders: Advocacy Networks in International Politics. Ithaca: Cornell University Press.

Kissinger, H. (2014). World Order. New York: Penguin Press.

Koremenos, B., Lipson, C., \& Snidal, D. (2001). The Rational Design of International Institutions. International Organization, 55(4), 761-799.

Kriesi, H., Grande, E., Lachat, R., Dolezal, M., Bornschier, S., \& Frey, T. (2006). Globalization and the Transformation of the National Political Space: Six European Countries. European Journal of Political Research, 45(6), 921-956.

Layne, C. (2012). This Time It's Real: The End of Unipolarity and the Pax Americana. International Studies Quarterly, 56(1), 203-213.

Lenz, T., \& Viola, L. (2017). Legitimacy and Institutional Change in International

Organizations: A Cognitive Approach. Review of International Studies, 43(5), 939-961.

Mansfield, E. C., \& Mutz, D. C. (2012). Support for Free Trade: Self-Interest, Socio-Tropic Politics, and Out-Group Anxiety. International Organization, 63(3), 425-457.

Marks, G., Attewell, D., Rovny, J., \& Hooghe, L. (2018). "The Social Bases of the Transnational Cleavage." Unpublished manuscript.

Mazur, J. (2000). Labor's New Internationalism. Foreign Affairs, 79(1), 79-93.

Morgenstern, S., Tamayo, A. B., Faucher, P., \& Nielson, D. (2007). Scope And Trade Agreements. Canadian Journal of Political Research, 40(1), 157-183.

Munck, R. (2007). Globalization and Contestation: The New Great Counter-Movement. New York: Routledge.

Mutz, D. C. (2018). Status Threat, Not Economic Hardship, Explains the 2016 Presidential Vote. Proceedings of the National Academy of Sciences of the United States of America, available at: www.pnas.org/cgi/doi/10.1073/pnas.1718155115, from April $23,2018$.

Mutz, D. C., \& Kim, E. (2017). The Impact of In-group Favoritism on Trade Preferences. International Organization, 71(4), 827-850.

Nielson, D. L., Hyde, S. D., \& Kelley, J. (2019). The Elusive Sources of Legitimacy Beliefs: Civil Society Views of International Election Observers. Review of International Organizations [this issue].

O’Brien, R., Goetz, A. M., Scholte, J. A., \& Williams, M. (Eds.) (2000). Contesting Global Governance: Multilateral Economic Institutions and Global Social Movements. Cambridge: Cambridge University Press.

Olivet, C., \& Brennan, B. 2010. Regional Social Policy from Below: Reclaiming Regional Integration: Social Movements and Civil Society Organizations as Key Protagonists. In B. Deacon, M. Macovei, L. Van Langenhove, \& N. Yeates (Eds.), World-Regional Social Policy and Global Governance: New Research and Policy Agendas in Africa, Asia, Europe and Latin America. London: Routledge. 
Polk, J., Rovny, J., Bakker, R., Edwards, E., Hooghe, L., Jolly, S., Koedam, J., Kostelka, F., Marks, G., Steenbergen, M., Vachudova, M., \& Zilovic, M. (2017). Explaining the Salience of Anti-Elitism and Reducing Political Corruption for Political Parties in Europe with the 2014 Chapel Hill Expert Survey Data. Research \& Politics, https://doi.org/10.1177/2053168016686915

Rathbun, B. C. (2012). Trust in International Cooperation: International Security Institutions, Domestic Politics, and American Multilateralism. New York: Cambridge University Press.

Rhodes, M., \& van Apeldoorn, B. (1997). Capitalism versus Capitalism in Western Europe. In M. Rhodes, P. Heywood, \& V. Wright (Eds.), Developments in West European Politics (pp. 171-189). New York: St. Martin's Press.

Ribeiro Hoffmann, A. (2015). Politicization and Legitimacy in Mercosur. In A. Hurrelmann, \& S. Schneider (Eds.), The Legitimacy of Regional Integration in Europe and the Americas (pp. 57-73). Houndmills: Palgrave Macmillan.

Rixen, T., \& Zangl, B. (2013). The Politicization of International Economic Institutions in US Public Debates. Review of International Organizations, 8(3), 363-387.

Rocabert, J., Schimmelfennig, F., Crasnic, L., \& Winzen, T. (2019). The Rise of International Parliamentary Institutions: Purpose and Legitimation. Review of International Organizations [this issue].

Romano, C., Alter, K. J., \& Shany, Y. (Eds.). (2014). The Oxford Handbook of International Adjudication. Oxford: Oxford University Press.

Ross, G. (1995). Jacques Delors and European Integration. Oxford: Oxford University Press.

Ruggie, J. G. (1982). International Regimes, Transactions, and Change: Embedded Liberalism in the Postwar Economic Order. International Organization, 36(2), 379415.

Rydgren, J. (Ed.). (2013). Class Politics and the Radical Right. London: Routledge.

Schimmelfennig, F., Winzen, T., Lenz, T., Rocabert, J., Crasnic, L., Gherasimov, C., Lipps, J., \& Mumford, D. (2018). "The Rise of International Parliaments: Strategic Legitimation in International Organizations." Unpublished book manuscript.

Schmidtke, H. (2019) Elite Legitimation and Delegitimation of International Organizations in the Media: Patterns and Explanations. Review of International Organizations [this issue].

Simmons, B. A. (2009). Mobilizing for Human Rights: International Law in Domestic Politics. Cambridge: Cambridge University Press.

Smith, J., Goodhart, M., Manning, P., \& Markoff, J. (Eds.). (2016). Social Movements and World-System Transformation. London: Routledge.

Spalding, R. J. (2007). Civil Society Engagement in Trade Negotiations: CAFTA Opposition Movements in El Salvador. Latin American Politics and Society, 49(4), 85-114. 
Steger, M. B., \& Wilson, E. K. (2012). Anti-Globalization or Alter-Globalization? Mapping the Political Ideology of the Global Justice Movement. International Studies Quarterly, 56(3), 439-454.

Tallberg, J., Sommerer, T., Squatrito, T., \& Jönsson, C. (2013). The Opening up of International Organizations: Transnational Access in Global Governance. Cambridge: Cambridge University Press.

Tallberg, J., \& Zürn, M. (2019). The Legitimacy and Legitimation of International Organizations: Introduction and Framework. Review of International Organizations [this issue].

Tarrow, S. (2005). The New Transnational Activism. Cambridge: Cambridge University Press.

Teney, C., Lacewell, O. P., \& De Wilde, P. (2014). Winners and Losers of Globalization in Europe: Attitudes and Ideologies. European Political Science Review, 6(4), 575-595.

Tsoukalis, L. (2014). The Unhappy State of the Union: Europe Needs a New Grand Bargain. London: Policy Network.

Van Elsas, E. J., Hakhverdian, A., \& van der Brug, W. (2016). United Against a Common Foe? The Nature and Origins of Euroscepticism among Left-Wing and Right-Wing Citizens. West European Politics, 39(6), 1181-1204.

Varoufakis, Y. (2017). Adults in the Room: My Battle with Europe's Deep Establishment. London: Bodley Head.

Whitefield, S., \& Rohrschneider, R. (2016). "Rethinking Right, Left and Centre: How International Issues are Reshaping European Party Competition." Paper presented at the Annual Conference of the European Consortium for Political Research, Prague.

Zürn, M. (2004). Global Governance and Legitimacy Problems. Government and Opposition, 39(2), 260-287.

Zürn, M. (2018). A Theory of Global Governance: Authority, Legitimacy, and Contestation. Oxford: Oxford University Press.

Zürn, M., Binder, M., \& Ecker-Ehrhardt, M. (2012). International Authority and Its Politicization. International Theory, 4(1), 69-106. 